\title{
An Assessment of the Factors that Influence the Use of Digital Technologies in Teaching: A Case Study
}

\author{
Rafail Prodani $^{1, *}$, Silvja Çobani ${ }^{2}$, Jozef Bushati $^{3}$, Aigars Andersons ${ }^{4}$ \\ ${ }^{1}$ Department of Informatics, Faculty of Natural and Human Sciences, University "Fan S. Noli", Albania \\ ${ }^{2}$ Department of Mathematics and Physics, Faculty of Natural and Human Sciences, University "Fan S. Noli”, Albania \\ ${ }^{3}$ Faculty of Education Sciences, University of Shkodra, "Luigj Gurakuqi", Albania \\ ${ }^{4}$ Faculty of Society and Science, Vidzeme University of Applied Sciences, Latvia
}

Received January 13, 2020; Revised February 25, 2020; Accepted March 12, 2020

Copyright $\odot 2020$ by authors, all rights reserved. Authors agree that this article remains permanently open access under the terms of the Creative Commons Attribution License 4.0 International License

\begin{abstract}
In the last decade we have a great development of Information and Communication Technologies (ICTs). As a result, educational institutions are increasingly incorporating these digital technologies into the teaching and learning process. Governments are making major investments to increase ICTs infrastructure in educational institutions and to train teachers to use these technologies in the teaching process. In this paper the main objectives of this study were to analy ze ICTs availability and use by students and by their teachers, their knowledge of different computer applications as well as their opinion about ICT use in learning. The study was conducted in the Korça region, located in the southeastern part of Albania. We will begin with a quick look at the level of access to digital technologies. Next we will study the use, knowledge and behavior of teachers and students towards digital technology and how these factors correlate with each other. The main focus will be on students as well as their perceptions about ICTs. This will be done by examining how much students know, use and how motivated they are to use digital technology. Questionnaires for teachers and students will be examined separately for each high school to see how these factors relate to and affect each other. At the end we will draw conclusions and make recommendations on how to maximize access and use of digital technologies by students in high schools.
\end{abstract}

Keywords Students, Learning, Knowledge, Information and Communication Technologies (ICTs), Digital Technologies, Teachers and Teaching

\section{Introduction}

Technologies such as the Internet, personal computers, and wireless telephony have turned the globe into an ever-growing network of individuals, businesses, governments, schools that communicate and interact with one another (ITG CID Harvard University, 2003).

Consequently, various educational institutions in our country, public and private, are trying to get involved in this network. Large investments are being made every year in the hope that Information and Communication Technology (ICT) will have a major positive impact on teaching outcomes.

Today ICT is becoming an important factor in the teaching and learning process. Teachers can use digital technology for easier and faster communication reasons, for saving time generally by using technology for different purposes when explaining different lectures, to manage lectures, seminars etc. Students, on the other hand, can use technological equipment for purposes such as expanding the knowledge of lectures explained by the teacher in the classroom by reading additional information while browsing the Internet, to communicate teachers and students, to take lectures, to develop exa mp les as well as to take assignments online and develop them with ICT assistance, to receive online secretarial services, etc.

Therefore, assessing the level of access and use of ICT in education is an important task that governments of each country should periodically to see the extent of implementation and the impact these investments have on the teaching and learning of students.

In Albania, ICTs inclusion components in secondary education went regularly in the mid-1990s. Today, computing has become a standard part of high school and nine year schools. Almost all high schools and nineteen-year-olds have computer labs and Internet access. There is a remaining problem of the qualification of the teachers of these schools, since in general they are not with the relevant education. Similarly Sheighold, (1991) states 
that:

"It is well understood that the challenge of technology integration in schools and classes is more human than technological. Moreover, it is not primarily about helping people to operate with a machine, but it is to help people, initially teachers, integrate these technologies into their teaching as tools of a profession being redefined through the process of incorporation."

This paper suggests that students' use of technology and their level of knowledge is strongly influenced by teachers' level of knowledge as well as teachers' attitude about ICT. The use of ICT in teaching from a student's perspective will also be seen. There is a tendency today in all developed and developing countries to incorporate technology into their education systems. In our country, right now, decision makers, policymakers, and educational authorities are trying to integrate technology into our education system. There is an expectation on their part for teachers to integrate teaching technology into their daily activities, because decisions about whether or not to use digital technology in classrooms are always made by teachers.

\section{Literature review}

Various scholars have done research in these areas and there is a broad consensus that there should be greater standardization regarding indicators that assess the access, use and impact of digital technologies on the teaching and learning process.

Countries all over the world have identified the significant role of information and communication technology in improving education (Kozma \& Anderson, 2002; Hennessy, Ruthven, \& Brindley, 2005). Pelgrum (2001) also emphasizes the quick rise of the Internet and worldwide web (WWW) have led to the adoption of objectives to equip all schools with access to these facilities in a relatively short period of time.

Moreover, ICTs are evolving at an increasingly rapid pace. Moore's Law tells us that the cost of computing is halved every 18 months. Gilder's Law tells us that the cost of bandwidth is being reduced even faster. Storage capacity is growing so fast that one can consider the actual cost to be approaching zero (Rory McGreal, 2014).

Significant investments have been made in Albania, in supporting physical infrastructure. As a result of these investments, there are about 1496 computer labs with a total of 24,125 computers. A report shows that our schools are moderately equipped with computers at the lowest level of technology in schools; see (Cate, Jessica W, 2017). According to reports, the internet is present in approximately all high schools, each of which has a dedicated broadband connection. Appropriate network infrastructure has been installed and configured in schools in Albania to enable teachers and students to utilize various resources to improve the teaching and learning process through the application of new technologies in education (The Open Society Foundations in Albania, 2015).

The teacher's role in the integration of computers in schools is obviously very important, and every educational reform effort should take into consideration teachers' knowledge, skills, beliefs, and attitudes (Cuban, 2000).

Kozma (2003) point out that positive impacts of technology depend on how much teachers use technology in their classes. Turbill (2001) identifies that there are three factors why teachers do not use technology in their classes: lack of time and expertise to understand and explore the software, lack of trust, and lack of training.

Kozma (2001) also emphasizes that special features of computers are needed to bring real life models and simulations to the learner, so the media does not interfere with the learning. Kozma points out that it is not the computer itself that makes the pupil learn but is designing of these models and stimuli, as well as the interaction of the pupils with them.

According to Patricia Wastiau et al. (2013), the following factors are the ones that should produce the key indicators:

- Schools' ICT infrastructure (desktop computer; mobile devices such as laptops, notebooks, tablets, smartphones, etc.; broadband; school website, email addresses, virtual learning environment, etc.; deployment of equipment in classrooms, computer labs, libraries, etc.; maintenance).

- Teachers' and students' access to ICT at school (years of experience using ICT at school, \% of time, frequency) and ICT-based activities organized by teachers and performed by students during lessons (frequency; type of activities; digital resources used).

- Teachers' and students' declared confidence in their digital competences (operational skills, social media skills, safe and responsible Internet use) and training (participation, content and modalities).

- Opinions and attitudes of school heads, teachers and students (ICT relevance for different learning processes; impact on learning, achievement and motivation).

\section{Methodology and Results}

The main objectives of this study were to analyze ICT availability and use by students and by their teachers in and out of the classroom, their knowledge of different computer applications as well as their opinion about ICT use in learning. As a means to attain these objectives by collecting reliable data, we conducted a survey with public high schools in the region of Korça, in southeastern Albania. The instruments used in this survey were two questionnaires: teachers' questionnaire and students'questionnaire.

Teachers' questionnaire was the Survey of Factors Affecting Teachers Teaching with Technology (also 
known as SFA-T3) designed by Papanastasiou, EC, \& Angeli, C. (2008). In addition to SFA-T3, a second questionnaire was designed to gather similar information from the students.

\subsection{The Sample}

The sample for this survey was designed in two stages:

- In the first stage, high schools were selected with probabilities according to their size and we ended up with seven of them.

- In the second stage, one class was randomly selected from each grade (i.e. grades 10, 11, 12), and all the students and all teachers teaching in the selected classes were surveyed. Classes were selected with equal probabilities within each school.

In the end, seven public high schools in the municipality of Korçë participated the study and the sample consists of 120 teachers and 360 students.

All schools that were asked were willing to participate in our survey, including the teachers and students of the respective randomly- selected clas ses.

Discussions with the principals of each school led to their assigning for each class a teacher who would help with the survey. These teachers made their classes available for the survey to take place.

Short intervie ws were conducted with school principals, where the school's ICT services and infrastructure was discussed.

The average age of the teachers who participated in the study was 42.18 years, with the minimum age being 25 years and the maximum age being 64 years old. They had an average of 13.58 years of teaching experience. 9 teachers $(7.5 \%$ of the sample) were in their first year of work, while 3 teachers $(2.5 \%$ of the sample) had 32 years of experience. The majority of teachers surveyed were female $(74.17 \%)$.

With regard to students, data shows that from total 360 students, $52(14.4 \%)$ students were 16 years old, $80(22.2 \%)$ students were 17 years old, $180(50 \%)$ students were 18 years old and $48(13.3 \%)$ students were 19 years old. 253 $(70.3 \%)$ were male and $107(29.7 \%)$ were female.

\subsection{ICT access and Use in and out of School}

As seen in the table 1, all seven schools have computer labs (one or more) and internet access, but only 3 of them are highly equipped.

With regard to ICT access out of school, the majority of the teachers $(97.50 \%)$ stated that they have computers at home and $79.17 \%$ of them even had attended professional development courses related to the integration of computers into teaching.

The frequency distribution of the teachers responses show that teachers rarely use specialized software application. They use common software applications more often instead.

As shown in Figure 1, on average teachers use common software applications several times a week, with the least frequently used software being once or twice a week or every day by only $4.2 \%$ of the teachers) and the most frequently used software being search engines for searching information (with $63.3 \%$ of respondents using it almost every day).

On the other hand, as seen in Figure 2, teachers use specialized software programs very rarely. The least frequently used software are programming languages (which are used once or twice a week or every day by only $5.9 \%$ of the teachers), and the most frequently used software is FrontPage/WordPress (with $32.5 \%$ of the teachers using it once or $t$ wice a week or almost every day).

Table 1. Some sample data

\begin{tabular}{|c|c|c|c|c|c|c|c|c|}
\hline School ID & $\begin{array}{c}\text { Nr. of } \\
\text { teachers }\end{array}$ & $\begin{array}{c}\text { Nr of } \\
\text { students }\end{array}$ & $\begin{array}{c}\text { Nr of computer } \\
\text { labs in school }\end{array}$ & $\begin{array}{c}\text { Nr of computers in } \\
\text { the lab }\end{array}$ & $\begin{array}{c}\text { Internet } \\
\text { access }\end{array}$ & Projector & Printer & $\begin{array}{c}\text { Smart } \\
\text { board }\end{array}$ \\
\hline A & 19 & 57 & 1 & 5 & Yes & 1 & 1 & 0 \\
\hline B & 20 & 60 & 1 & 10 & Yes & 1 & 1 & 0 \\
\hline C & 18 & 54 & 1 & 15 & Yes & 1 & 1 & 0 \\
\hline D & 17 & 51 & 1 & 20 & Yes & 1 & 1 & 0 \\
\hline E & 16 & 48 & 2 & 12,13 & Yes & 2 & 1 & 1 \\
\hline F & 15 & 45 & 2 & 11,14 & Yes & 2 & 1 & 1 \\
\hline G & 15 & 45 & 3 & $10,11,12$ & Yes & 3 & 1 & 1 \\
\hline Total & 120 & 360 & & & & & & \\
\hline
\end{tabular}




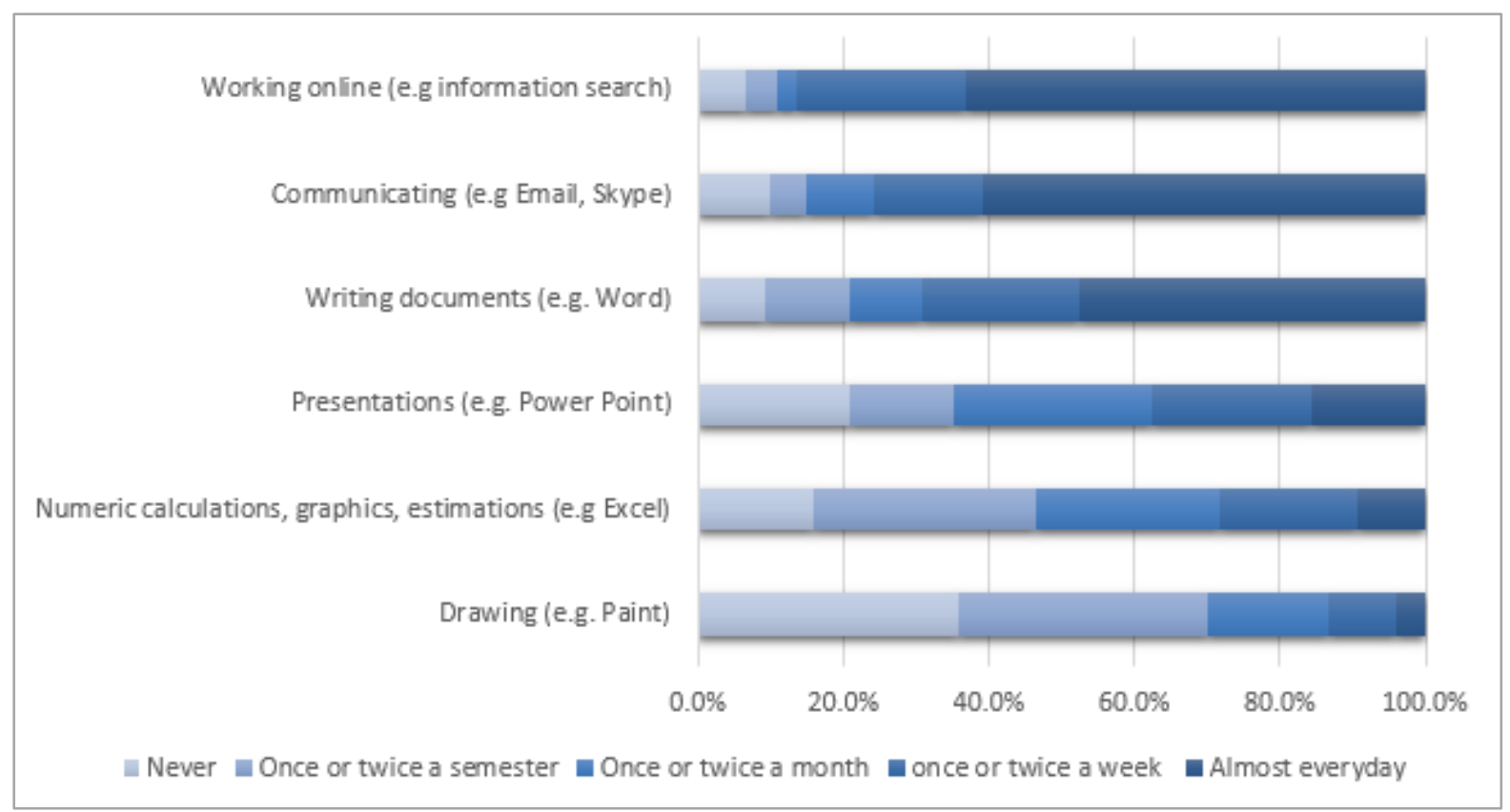

Figure 1. Teachers' use of common software

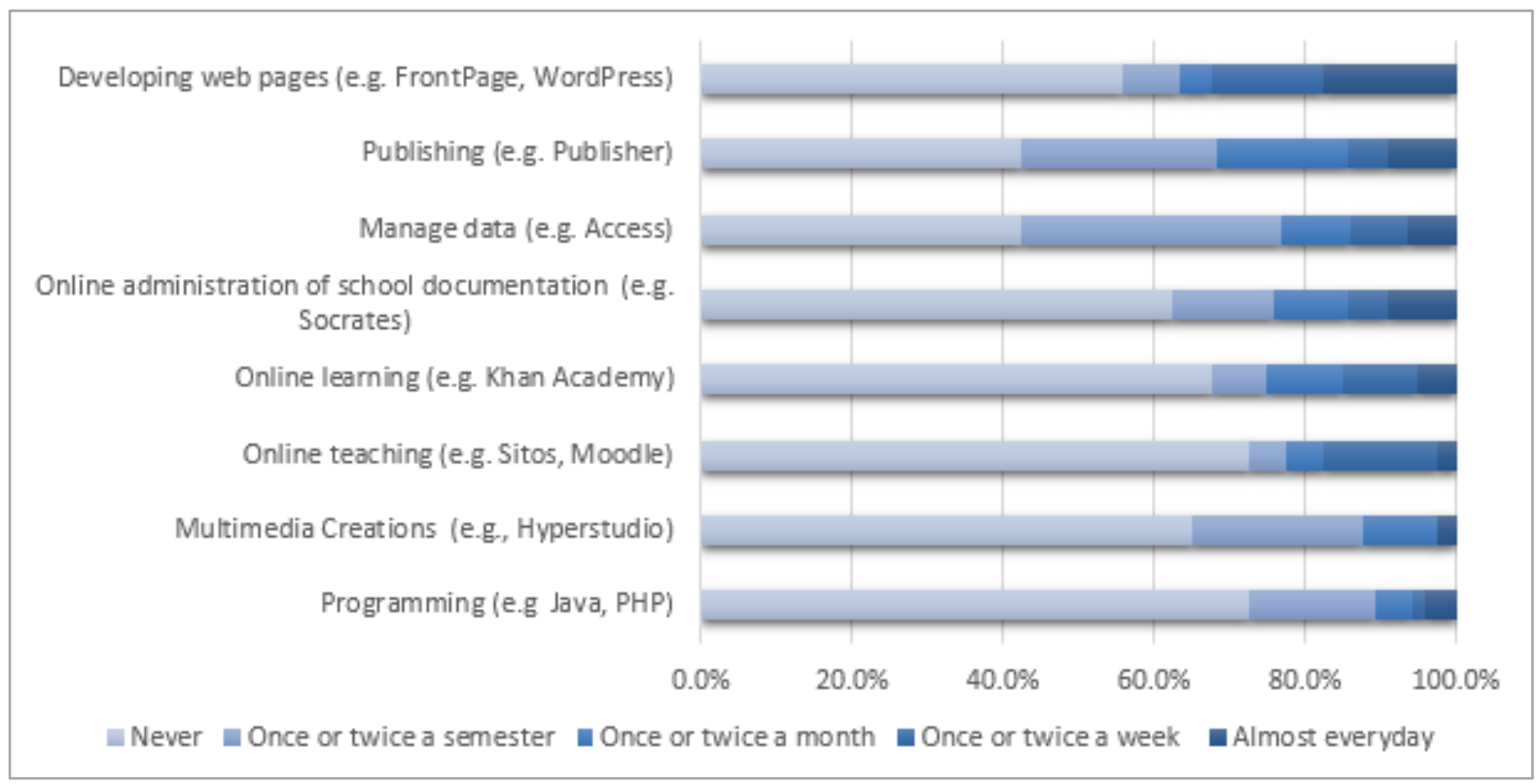

Figure 2. Teachers' use of specialized software

With regard to the students, the majority of them $(65 \%)$ stated that they had computers at home and $52.5 \%$ of them had completed additional ICT courses to help them improve their computer knowledge. In respect of the students ICT use at home and school, $50.8 \%$ of them use their computers every day outside school and $40.3 \%$ of them use it once or twice a week at school (as shown in Figure 3)
The examination of the students' responses showed a low total frequency with which students use ICT in specific school subjects. As shown in Figure 4, most of the students use computer software not often. They use computer software mostly in the subject of ICT (with $34.4 \%$ of the respondents using them every day) and less in mathematics (where they are used once or twice a week only by $0.6 \%$ of the respondents). 


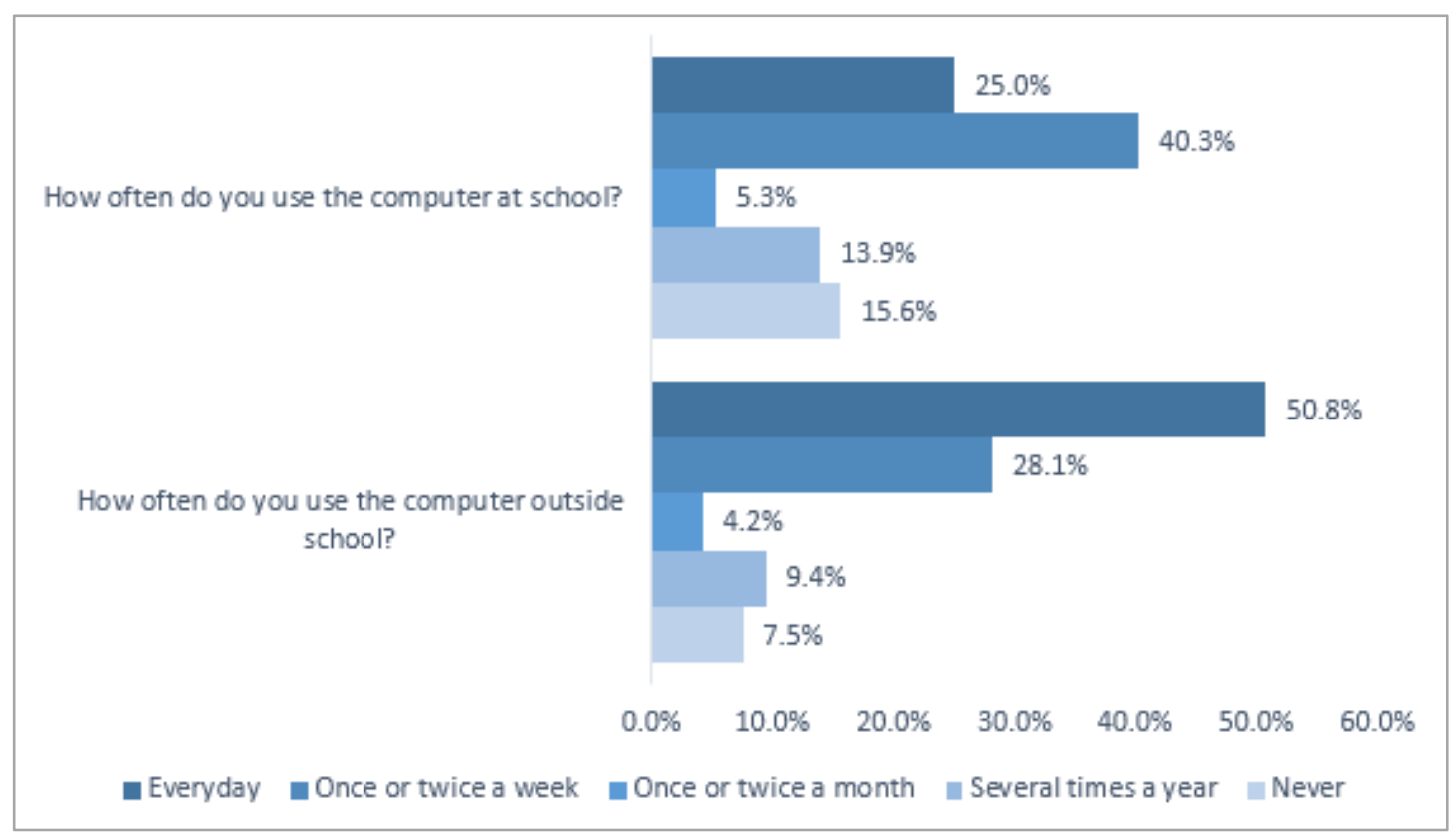

Figure 3. Students access to a computer in and out of school

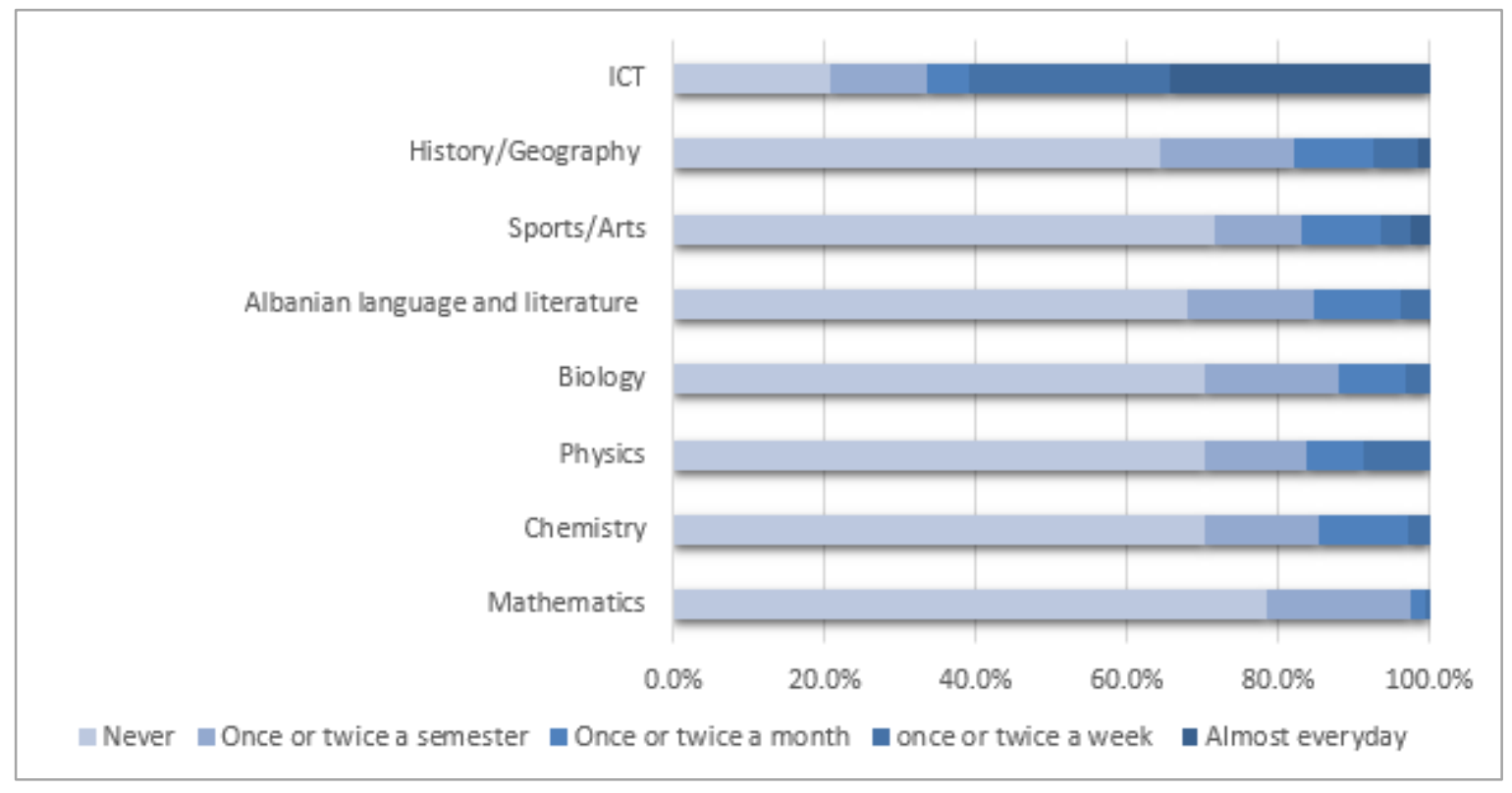

Figure 4. Students ICT use in specific school subjects

The short interviews conducted with the principals revealed a lot about the current situation of ICT services and infrastructure in the schools. All principals expressed concern about the minimal level of ICT support provided in school, and mainly the lack of an actual ICT specialist. According to them, despite teachers attending ICT courses, they still feel unsure about relying on ICT for their teaching. Some principals even suggested that an ICT specialist in school could have a positive effect on teachers' attitude towards using ICT in their teaching.

\subsection{Results}

After non-response adjustments, the gathered data was analyzed by using SPSS software version 20 . Some of the items in teachers and students questionnaires were designed to be used in analyses as single items (e.g. gender, age etc.), but most could not be observed directly as they were designed to be combined in some way in order to measure a specific factor. For the later items, a factor analysis was conducted (using Varimax rotation method with SPSS software). 
Table 2. Reliability Statistics

\begin{tabular}{|l|l|l|l|l|}
\hline \multicolumn{2}{l}{} & Sections & Cronbach's Alpha & N of Items \\
\hline \multirow{5}{*}{ Teachers Questionnaire } & 1 & Knowledge of computer software & .892 & 15 \\
\cline { 2 - 5 } & 2 & Frequency of using software & .804 & 15 \\
\cline { 2 - 5 } & 3 & Attitude towards integrating computers in teaching & .807 & 13 \\
\cline { 2 - 5 } & 4 & Self-confidence in the integration of digital technology & .852 & 8 \\
\cline { 2 - 5 } & 5 & School climate and support & .905 & 6 \\
\hline \multirow{5}{*}{$\begin{array}{l}\text { Students } \\
\text { Questionnaire }\end{array}$} & 1 & Information on ICT use & .659 & 10 \\
\cline { 2 - 5 } & 2 & Frequency of using soft ware & .863 & 14 \\
\cline { 2 - 5 } & 3 & Attitude towards ICT use in learning & .614 & 8 \\
\cline { 2 - 5 } & 4 & Knowledge of computer software & .878 & 13 \\
\cline { 2 - 5 } & 5 & Interest in learning computer software & .893 & 10 \\
\hline
\end{tabular}

Table 3. Inter-factor correlations

\begin{tabular}{|c|c|c|c|c|c|}
\hline & $\begin{array}{c}\text { ICT Access and } \\
\text { support }\end{array}$ & $\begin{array}{c}\text { Students' ICT } \\
\text { use }\end{array}$ & $\begin{array}{c}\text { Students' support of } \\
\text { ICT use }\end{array}$ & $\begin{array}{c}\text { Students' ICT } \\
\text { knowledge }\end{array}$ & $\begin{array}{c}\text { Students' interest in learning } \\
\text { computer }\end{array}$ \\
\hline Students' ICT use & $.295^{*}$ & 1 & & & \\
\hline Students' support of ICT use & $.460^{*}$ & $.478^{*}$ & 1 & & \\
\hline Students' ICT Knowledge & $.223^{*}$ & $.405^{*}$ & $.354^{*}$ &. & 1 \\
\hline $\begin{array}{c}\text { Students' interest in learning } \\
\text { computer }\end{array}$ & $.497^{*}$ & $.445^{*}$ & $.529^{* *}$ & $.651^{*}$ & $.675^{* *}$ \\
\hline Teacher's ICT knowledge & $.413^{* *}$ & $.213^{*}$ & $.598^{* *}$ & $.610^{*}$ & $.574^{* *}$ \\
\hline Teacher's ICT use & $.544^{*}$ & $.132^{*}$ & $.477^{*}$ & $.427^{*}$ & $.240^{* *}$ \\
\hline Teacher's confidence & $.655^{*}$ & $.328^{*}$ & $.592^{*}$ & $.342^{*}$ & $.568^{*}$ \\
\hline $\begin{array}{c}\text { Teacher positive attitude } \\
\text { towards ICT }\end{array}$ & $.590^{*}$ & $.177^{*}$ & $.567^{* *}$ & $.482^{* *}$ & \\
\hline
\end{tabular}

**. Correlation is significant at the 0.01 level (2-tailed).

*. Correlation is significant at the 0.05 level (2-tailed).

The Cronbach's alpha calculation, seen in Table 2, showed that both the SFA-T3 and the students' questionnaire have relatively high internal consistency.

By means of factor analysis (the Varimax rotation method with eigenvalues greater than 1), we were able to identify the factors that push teachers towards integrating technology in teaching. These factors are:

1) Knowledge of software applications; 2) Use of software applications; 3) Self- Confidence; 4) Positive attitude towards the use of ICT in teaching; 5) ICT access and support.

The data gathered by the students' questionnaire was analyzed in a similar way and the following factors were produced:

1) Use of software applications (at school or home); 2) Knowledge of software applications; 3) Support of ICT use; 4) Interest in learning computer software.

Lastly, but most importantly, the Pearson's correlation was computed at school level to study the correlations between the aforementioned factors. Table 3 shows the relations we discovered.

- ICT access and support in school is positively correlated to teachers' computer use $(r=0.413)$. So digitally supportive schools tend to encourage teachers to use computers more.
- ICT access and support in school is positively correlated to teachers' confidence $(r=0.655)$ and positive attitude towards the use of ICT in teaching $(r=0.590)$. This means that digitally supportive schools have more teachers that are confident in their knowledge of computer software and tend to use them more often in their teaching.

- ICT access and support in school is positively correlated to students' computer knowledge $(\mathrm{r}=0.223)$ used at school or at home $(r=0.295)$. So digitally supportive schools have students with better computer knowledge and students use computer more often.

- Teachers' confidence $(r=0.592)$ and positive attitude towards using ICT in teaching $(\mathrm{r}=567)$ are positively correlated with students' support of ICT use. So, the most digitally supportive students can be found in the schools where teachers are not scared to rely on ICT for their teaching.

\section{Conclusions}

The use of technology in class in order to support the teaching process is a necessity especially for the today's 
society. There are teachers in Albanian schools who still use traditional methods focusing mainly on the teacher, considering themselves as distributors and only source of knowledge.

The factor analysis conducted in this study identified the potential factors that could encourage teachers to regard ICT as a useful teaching tool. Factors influencing students ICT knowledge and interest were als o identified.

The inter-correlations between the aforementioned factors gave us some interesting findings. As can be seen from Table 3, "ICT Access and support" at school is a major factor because it affects all other factors and most importantly, "Teacher's confidence", "Teacher positive attitude towards ICT", "Teacher's ICT use" and "Students' interest in learning computer software". "Teacher's ICT knowledge" also emerges as another major factor affecting other factors such as "Students' interest in learning computer software", "Students' ICT knowledge" and "Students' support of ICT use". "Teacher positive attitude towards ICT" is another factor that influences factors such as "Students' interest in learning computer", "Students' ICT knowledge" and "Students' support of ICT use". So, if we want to increase the level of ICT knowledge and use by students, we need to increase the level of access and support for ICT at school, increase teacher preparation in ICT-related areas and try to motivate the teacher to have a more positive attitude towards the use of ICT in teaching.

Today in Korça region almost all high schools have broadband Internet and especially high schools, in or near the city of Korça, are equipped with one or two functional computer labs. Most of the schools lack computers and other digital devices in the classrooms. Also from interviews with school principals, it seems clear that school support for ICT is at a minimal level.

So, taking into consideration the above findings and correlations' analysis, it does not come as a surprise the fact revealed by the student questionnaires that the use of ICT in subjects such as Mathematics, Physics, Biology, Che mistry, History, Geography, Albanian Language and Literature is on average once or twice a semester, a very low level of use.

This results lead us to agree with the suggestions of Hew, K. F., \& Brush, T. (2007) for helping teachers overcome barriers in technology integration by establishing computers in classes instead of having them in a computer lab, providing schools with laptops cards, by teaching in small groups, or approach with centers where computers are used. Consideration should be given to the continuous training of teachers on most used programming languages and new web technologies, as ICTs change very rapidly. Teachers need to be familiar with these hanges as soon as possible in order to be better prepared and feel confident in applying technologies to teaching. High schools should have ICT specialists, who are absent today and who will handle computer lab maintenance and information systems, as well as the technical support of teachers during the process of using digital technology in teaching.

Also, we agree with what Cuban (2001) indicates that technology reform efforts have failed because teachers' beliefs, skills, and attitudes have never been taken into consideration. Teachers need to have more opportunities of professional growth as provided by higher administrative bodies so as to support them in using technology in class. (Hew, K. F., \& Brush, T., 2007 and Barone, D., \& Wright, T. E., 2009).

\section{REFERENCES}

[1] Barone, D., \& Wright, T. E. Literacy instruction with digital and media technologies. The Reading Teacher, 62(4), 292-309, 2009.

[2] Cuban, L. So much high-tech money invested, so little use and chan ge in practice: How come? Paper presented for the Council of Chief State School Officers' Annual Technology Leadership Conference, Washington, DC, 2000.

[3] Cate, Jessica W., "Students to Computer Ratio, Socioeconomic Status, and Student Achievement" Electronic Theses and Dissertations. Paper 3284, pg 54-55, 2017. https://dc.etsu.edu/etd/3284

[4] Cuban, L. So much high-tech money invested, so little use and chan ge in practice: How come? Paper, presented for the Council of Chief State School Officers' Annual Technology Leadership Conference, Washington, DC, 2000.

[5] Cuban, L. Oversold \& Underused: Computers in the Classroom. Cambridge, MA:: Harvard University Press, 2001.

[6] Hennessy, S., Ruthven, K. \& Brindley, S. Teacher perspectives on integrating ICT into subject teaching: commitment, constraints, caution, and change. Journal of Curriculum Studies, 37(2), 155-192, 2005. https://www.ed uc.cam.ac.uk/research/projects/ist1/WP042.pdf

[7] Hew, K. F., \& Brush, T. Integrating technology into K-12 teaching and learning: currentknowledge gags and recommendations for future research. Education Tech Research Dev, 55,, 223-252, $2007 . \quad$ doi: 10.1007/s11423-006-9022-5.

[8] ITG CID Harvard University, "Readiness for the Networked World. A Guide for Developing Countries", 2003. Retrieved from http://www.readinessguide.org.

[9] Kozma, R. B. Counterpoint theory of 'learning with media' In R. E. Clark (Ed), Learning from media: Arguments, analysis, and evidence Greenwich, CT: Information Age Publishing Inc, pp 137-178, 2001.

[10] Kozma, R. \& Anderson R. E. Qualitative case studies of innovative pedagogical practices using ICT. Journal of Computer Assisted Learning, 18, 387-394, 2002.

[11] Kozma, R. B. Technology and classroom practices: An international study. Journal of Research on Technology in Education, 36(1), 1-14, 2003.

[12] Papanastasiou, E. C., \& Angeli, C. Evaluating the Use of 
ICT in Education: Psy chometric Properties of the Survey of Factors Affecting Teachers Teaching with Technology (SFA-T3). Educational Technology \& Society, 11 (1), 69-86, 2008.

[13] Patricia Wastiau, Roger Blamire, Caroline Kearney, Valerie Quittre, Eva Van de Gaer \& Christian Monseur, The Use of ICT in Education: a survey of schools in Europe. 2013 Blackwell Publishing Ltd., 9600 Garsington Road, Oxford OX4 2DQ, UK and 350 Main Street, Malden, MA 02148, USA, 2013:

[14] Pelgrum, W. Obstacles to the integration of ICT in education: Results from a worldwide educational assessment. Computers \& Education, 37, 163-178, 2001.

[15] Rory MoGreal, Why Open Educational Resources Are Needed for Mobile Learning. PER SPECTIVES ON OPEN AND DISTANCE LEARNING: Increasing Access through Mobile Learning Mohamed Ally and Avgoustos Tsinakos, Editors. Commonwealth of Learning and Athabasca University, 2014, 49-61, 2014.

[16] Sheighold, K. Restructuring for learning withtechnology: The potential for synergy. Phi Delta Kappan, 73(1), 17-27, 1991.

[17] The Open Society Foundations in Albania, "Integrimi i Teknologisë së Informacionit dhe Komunikimit në Edukim në Shqipëri”, Tiranë, June, 2015. https://altri.al/wp-content /uploads/2018/05/Studimi-e-learning-shqip.pdf

[18] Turbill, J. A researcher goes to school: using new technology in the kindergarten literacy curriculum. Journal of Early Childhood Literacy, 1(3),, 255-279, 2001. 